\title{
Morphological changes in the ovaries of the sea urchin Strongylocentrotus intermedius exposed to cadmium
}

\author{
S. M. Gnezdilova ${ }^{1}$, I. G. Lipina ${ }^{1} \&$ N. K. Khristoforova ${ }^{2}$ \\ ${ }^{1}$ Laboratory of Gametogenesis, Institute of Marine Biology, and ${ }^{2}$ Laboratory of Geochemistry, Pacific Institute of Geography, \\ Far East Science Center, Academy of Sciences of the USSR, Vladivostok 690022, USSR
}

\begin{abstract}
A morphological study was conducted on ovaries of the sea urchin Strongylocentrotus intermedius exposed to cadmium chloride in concentrations of 50 and $100 \mu \mathrm{g} \mathrm{l}^{-1}$ during 15, 40, 72 and $130 \mathrm{~d}$. Long-term cadmium exposure resulted in qualitative and quantitative changes in gonads during oogenesis. Cadmium exposure resulted in (1) degenerative changes in growing oocytes and accessory cells, and necrosis of acini; and (2) a temporary increase in the number of oogonia and attached oocytes in comparison to the control. An increased (relative to control) production of oogonia in exchange for resorbing oocytes demonstrated a response of the sex gland to an unfavourable impact.
\end{abstract}

\section{INTRODUCTION}

Exposure of the mature sea urchin Strongylocentrotus intermedius to cadmium results in production of abnormal gametes and non-viable offspring, in spite of the absence of obvious histological changes in sea urchin ovaries (Khristoforova et al. 1984). This paper develops our earlier investigations and presents an electron-microscopic study of a gonadotoxic effect of cadmium at a chronic exposure of test specimens to sublethal doses of cadmium chloride.

\section{MATERIAL AND METHODS}

The experiment was conducted at the 'Vityaz' marine field station of the Far East Science Center (USSR Acad. Sci.) at Possjet Bay, Sea of Japan, from April to August 1983. Two hundred sea urchins were collected in the bay, divided into 3 groups (1 control and 2 test groups) and placed in three 1001 closed aerated aquaria. Cadmium chloride $\left(\mathrm{CdCl}_{2} 2.5 \mathrm{H}_{2} \mathrm{O}\right)$ was added to aquarium water to obtain concentrations of $50 \mu \mathrm{g} \mathrm{Cd}^{-1}$ (Test Group I) and $100 \mu \mathrm{g} \mathrm{Cd}^{-1}$ (Test Group II). Aquarium water was changed daily and sea urchins were fed on the seaweeds Ulva and Laminaria. After $5 \mathrm{~d}$ of adaptation of test specimens, we used temperature stimulation to enhance growth of gametes: water temperature rose from $3^{\circ} \mathrm{C}$ over $40 \mathrm{~d}$ to 10 to $11^{\circ} \mathrm{C}$ (Evdokimov 1974). Sexual maturity of sea urchins was established using electric shock, and mature females were taken from the aquaria for histological examination of their sex gland. In the remaining specimens, oogenesis ran synchronously. After $40 \mathrm{~d}$ of the experiment, aquarium water became warmer due to an ambient temperature rise and reached $18^{\circ} \mathrm{C}$ by the end of the experiment.

We analyzed altogether more than 120 individuals, 10 in each control and test group for each concentration at time intervals of $15,40,72$ and $130 \mathrm{~d}$.

For histological examination, gonads of sea urchins were fixed after $15,40,72$ and $130 \mathrm{~d}$ of cadmium exposure in ethanol-acetic acid mixture $(3: 1)$ and imbedded in paraffin. Sections were cut $5 \mu \mathrm{m}$ thick and stained in Caracci hematoxylin and $1 \%$ eosin. Oogonia, wall-attached and free oocytes, egg cells and resorbing gametes were counted in each of 50 acini for every female analyzed. The acinus area, S, was calculated according to the formula

$$
\mathrm{S}=\pi \frac{\mathrm{d}_{1} \cdot \mathrm{d}_{2}}{4}
$$

where $\mathrm{d}_{1}=$ the long diameter, and $\mathrm{d}_{2}=$ the short diameter of an acinus (Khesin 1967). For each female, 50 acini were measured and the mean acinus area was calculated for each group of 10 individuals. The aver- 
age number of each cell type (oogonia, wall-attached and free oocytes, egg cells and resorbing gametes) was estimated per one 'mean' acinus. The data were statistically processed using Student's t-test $(p<0.05)$.

For an electron microscopic examination, ovary

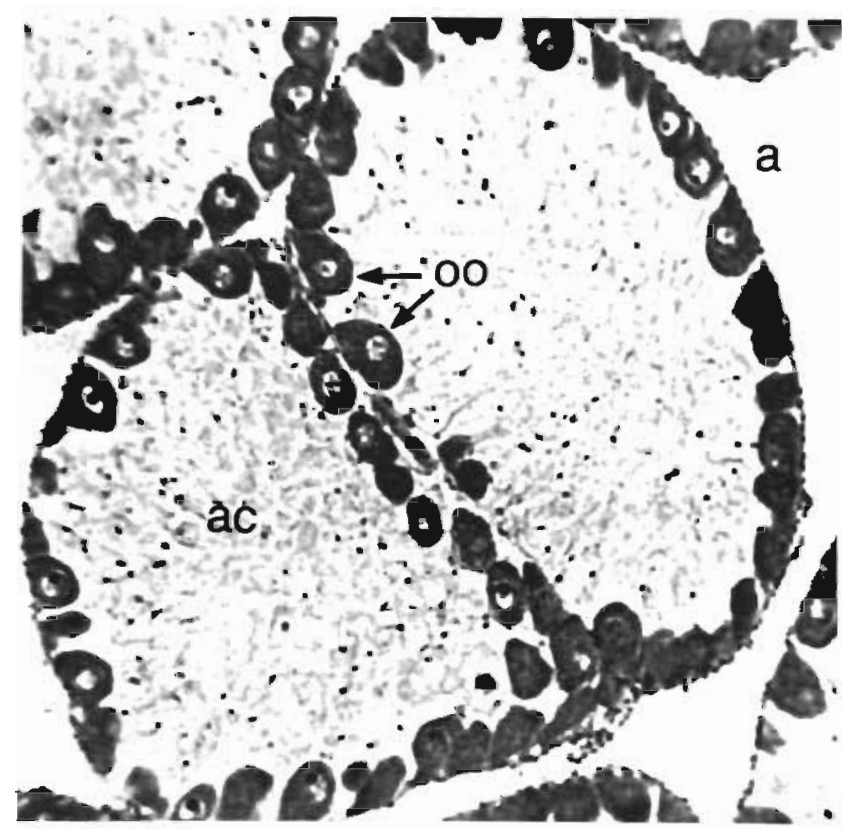

Fig. 1. Strongylocentrotus intermedius. Micrograph of normal sea urchin gonad. Stain: Caracci hematoxylin. a: acinus; oo: oocytes; ac: accessory cells. $420 \times$ pieces were fixed at $4{ }^{\circ} \mathrm{C}$ for $2 \mathrm{~h}$ in $2.5 \%$ solution of glutaraldehyde, $0.1 \mathrm{M}$ phosphate buffer ( $\mathrm{pH} 7.8$ ) with $0.5 \%$ solution of neutral formalin and $17 \%$ solution of saccharose. Post-fixation for $1 \mathrm{~h}$ was done with $1 \%$ $\mathrm{OsO}_{4}$ solution in the phosphate buffer with $27 \%$ saccharose. After dehydration in increasing grades of alcohol, ovary pieces were imbedded in Epon 812. Ultrathin sections were contrasted with uranyl acetate and lead citrate, examined and photographed on an electron microscope Jem-100 B.

\section{RESULTS}

In the sea urchin Strongylocentrotus intermedius, oogonia (poorly differentiated sex cells) develop into oocytes in acini (end portions of the gonad). In terms of disposition within the acinus, we distinguished attached oogonia connected with the acinus wall and free oocytes lying in the acinus lumen. During cell division, oocytes develop into egg cells to be spawned (Gnezdilova 1971). In addition to sex cells, female gonads contain accessory cells with a great number of various globules in cytoplasm. The accessory cells have a supporting and trophic function; they participate in resorption of oocytes (Varaksina 1980). We distinguish 5 stages in the gonad development in the sea urchin S. intermedius: (1) passivity, (2) beginning of growth, (3) active gametogenesis, (4) pre-spawning, and (5) spawning (Gnezdilova 1971).

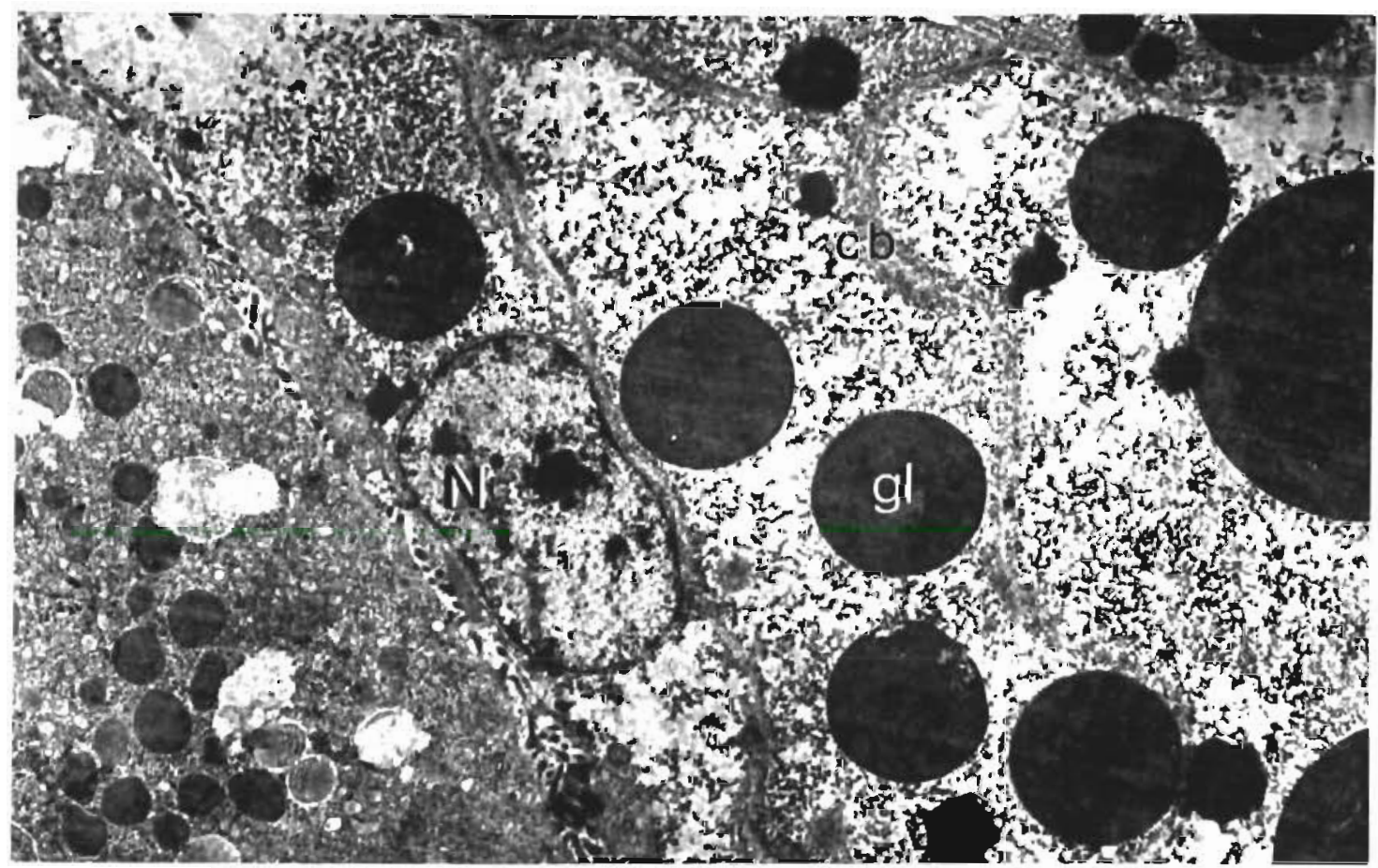

Fig. 2. Strongylocentrotus intermedius. Electronogram of accessory cells in normal gonads of sea urchin. N: nucleus; gl: globules; cb: cell borders. $6000 \times$ 

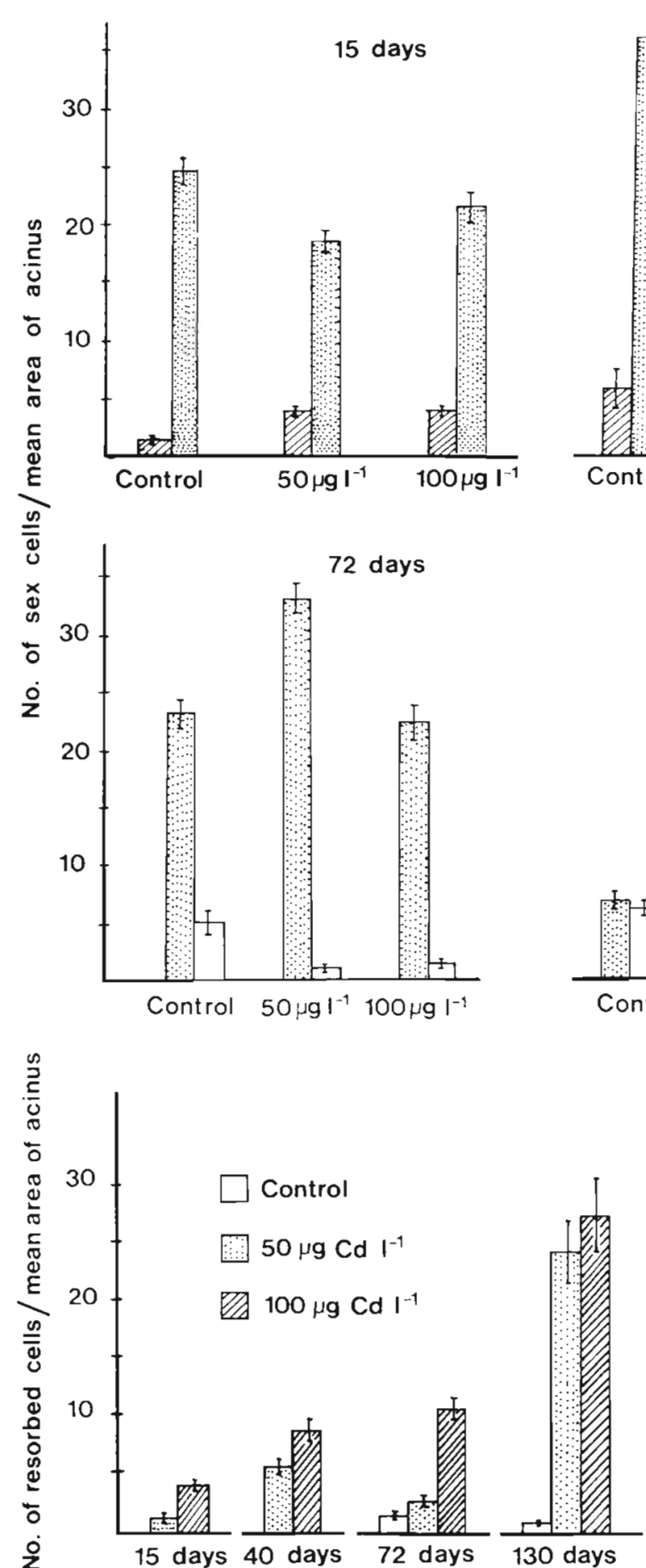

Fig. 4. Strongylocentrotus intermedius. Number of resorbed cells in ovaries of Cd-exposed sea urchin (per mean area of acinus) as a function of cadmium concentration and duration of exposure (mean value for $n=10$ in each group for each concentration). $\mathrm{p}<0.05$

Before the experiment, gonads of intact sea urchins were in the 2nd developmental stage: the basal membrane of acini supported oogonia and small oocytes (Fig. 1); a major part of acini was occupied by
40 days

Oogonia

Wall-attached oocytes

Free-lying oocytes

Egg cells
Fig. 3. Strongylocentrotus intermedius. Number of sex cells in ovaries of Cd-exposed sea urchins (per mean area of acinus) as a function of cadmium concentration and duration of exposure (mean value for $\mathrm{n}=10$ in each group for each concentration) $\mathrm{p}<0.05$ accessory cells with distinct ovate globules in cytoplasm (Fig. 2).

We did not observe any changes in feeding behaviour of test specimens as a result of $\mathrm{Cd}$ treatment. It seems that the direct impact of $\mathrm{Cd}$-contaminated medium and indirect nutritional effect caused by feeding on Ulva and Laminaria within the medium were both responsible for $\mathrm{Cd}$ uptake by the sea urchins in the experiment.

\section{Comparison of gonads in control and test specimens}

After $15 \mathrm{~d}$ of exposure, gonads of control and test specimens remained in the 2 nd developmental stage. Cadmium in concentrations of 50 and $100 \mu \mathrm{gl}^{-1}$ caused both a rise in the number of oogonia as compared to the control (Fig. 3) and resorption of growing oocytes (Fig. 4). A comparison with the control showed statistically significant differences for all the values measured. No morphological damage of accessory cells was observed at this time.

By the 40th day of the experiment, gonads of some 
control and test specimens were already in the spawning stage. Mature female sea urchins were removed from aquaria. A histological analysis showed that the gonads of remaining individuals were in the $3 \mathrm{rd}$ developmental stage (active gametogenesis). Acini contained large attached and free oocytes. Both cadmium concentrations tested caused a statistically significant decrease in gamete number (about $20 \%$ ).
Resorption of cells progressed in test specimens. We counted sex cells with signs of resorption: appearance of small vacuoles in cytoplasm, condensation of nuclear chromatine in the peripheral portions of the envelope, increased density of cytoplasm and irregular form and pycnosis of cell nuclei (Fig. 5). Resorption involved large attached and free oocytes in the vitellogenic phase, egg cells and, to a lesser extent, pre-

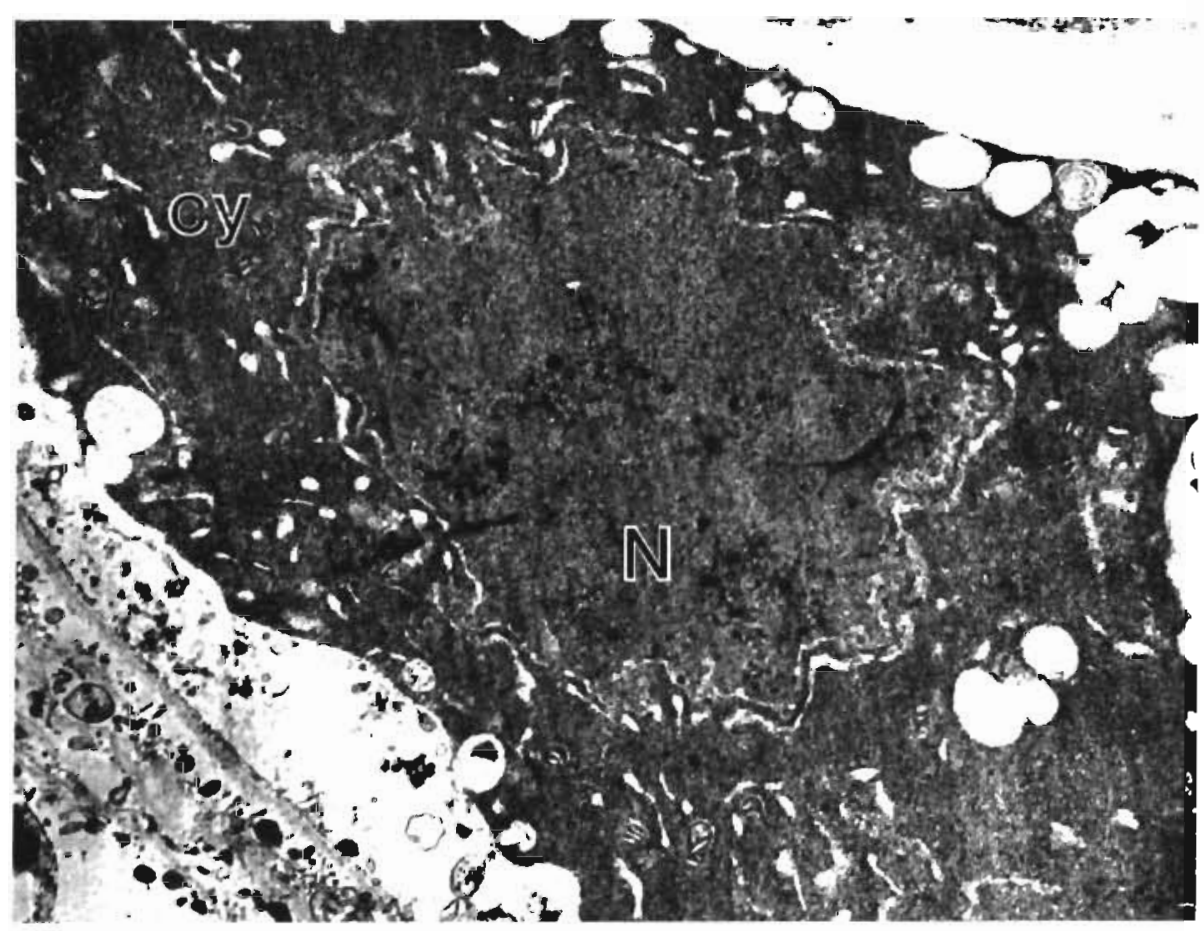

Fig. 5. Strongylocentrotus intermedius. Electronogram of destruction of oocytes in sea urchin gonad after exposure to cadmium. $N$ : nucleus; cy: cytoplasm. $6000 \times$

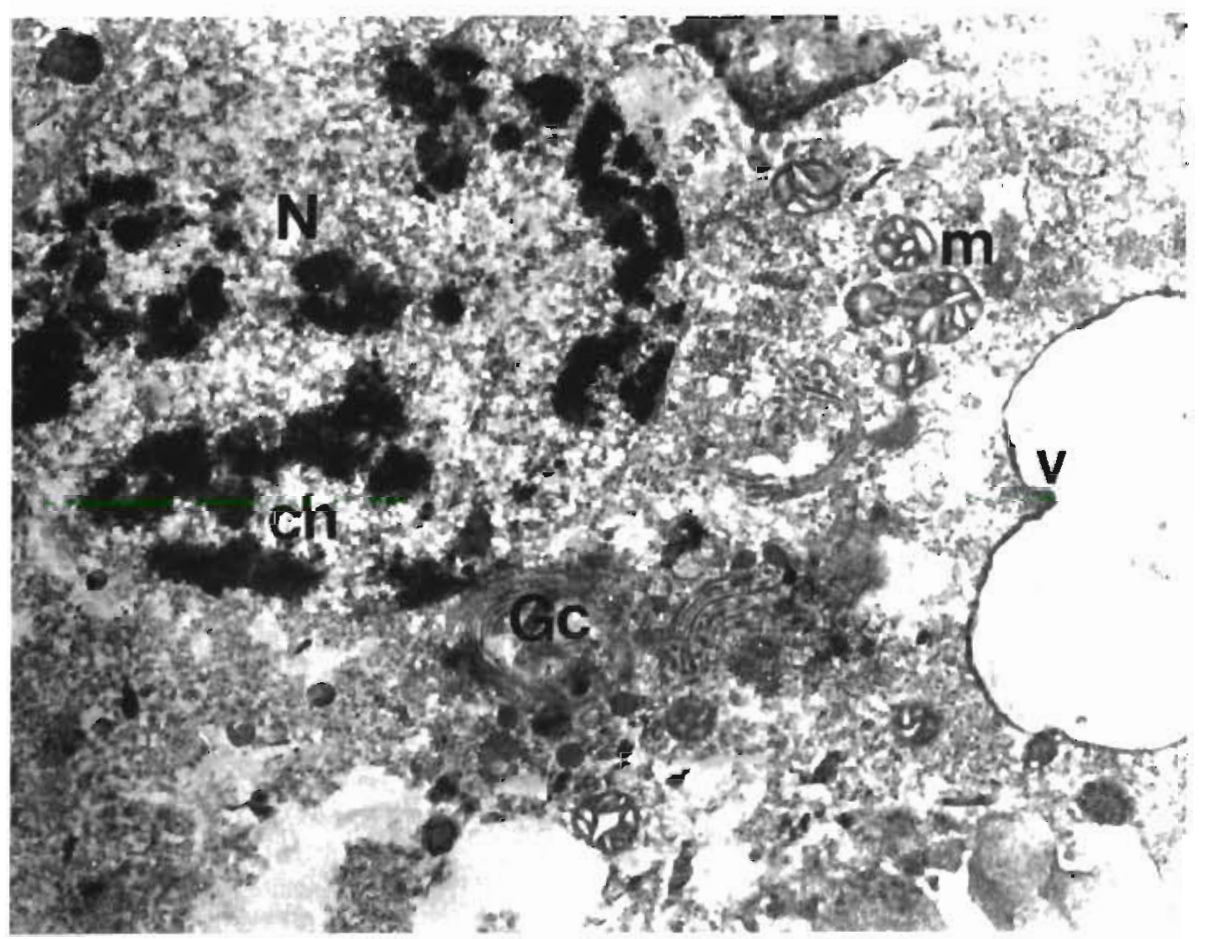

Fig. 6. Strongylocentrotus intermedius. Electronogram of accessory cells in sea urchin gonad after exposure to cadmium. N: nucleus; $v$ : vacuoles; $m$ : mitochondria; ch: chromatin; Gc: Golgi complex. $10000 \times$ 
vitellogenic oocytes. Degeneration of attached sex cells started in the apical portion of cells. Oocyte remains were resorbed by accessory cells, globules in their cytoplasm grew in number, and some gigantic granules, heterophagosomes, appeared. Resorption of gametes was accompanied by destruction of accessory cells. Damage to accessory cells was shown by the same changes as in oocytes and, in addition, by widening of the endoplasmic reticulum canals and by irregular arrangement of ribosomes over the canal surfaces (Fig. 6)

At Day 72 of exposure, gonads of controls remained in the 3rd developmental stage. In sea urchins of both Cd-exposed groups, gonads entered the 3rd stage; their acini contained mostly large attached oocytes and few free cells.

In gonads of sea urchins exposed to concentrations of $50 \mu \mathrm{g} \mathrm{l}^{-1}$, the number of attached oocytes increased in comparison to the control. Both concentrations tested enhanced resorption by Day 72. Destruction of sex and accessory cells led to formation of vast necrotic areas. As accessory cells are closely interconnected by their processes and surround growing oocytes (Fig. 7), their destruction enhances degeneration of acini and causes general lysis of cells (Fig. 8).

By Day 130, gonads of control sea urchins attained the pre-spawning ( 4 th) stage: large free-lying oocytes and ripe egg cells were seen in acini. Gonads of sea urchins in both test groups remained in the state of active gametogenesis. As previously, cadmium exposure produced 2 different effects: the number of attached oocytes increased 3.0 to 3.5 times in comparison to the control and, on the other hand, resorption of growing gametes progressed; increased resorption involved the entire acini (Fig. 9). The surface of some acini suffered desquamation of the celomic epithelial cells.

\section{DISCUSSION}

Different responses of animals to detrimental effects of the environment can be traced to various levels of life organization. Normal reproduction, high fertility rate and good viability of the offspring are critical for survival of an individual and preservation of the species. Cadmium was repeatedly reported to cause reproduction disturbances: a decrease in the hatching rate and damage to the outer egg envelope in fish (Westernhagen et al. 1974) and decreased number of normal larvae in oyster Crassostrea virginica (Zaroogian \& Morrison 1981) and sea urchins (Khristoforova et al. 1984). Our observations have shown that these abnormalities can result from disturbances in gametogenesis.

In the present study, long-term exposure of the sea urchin Strongylocentrotus intermedius to cadmium was followed by qualitative and quantitative changes in the development of oocytes. Morphometric analysis showed an increase in the number of oogonia after $15 \mathrm{~d}$

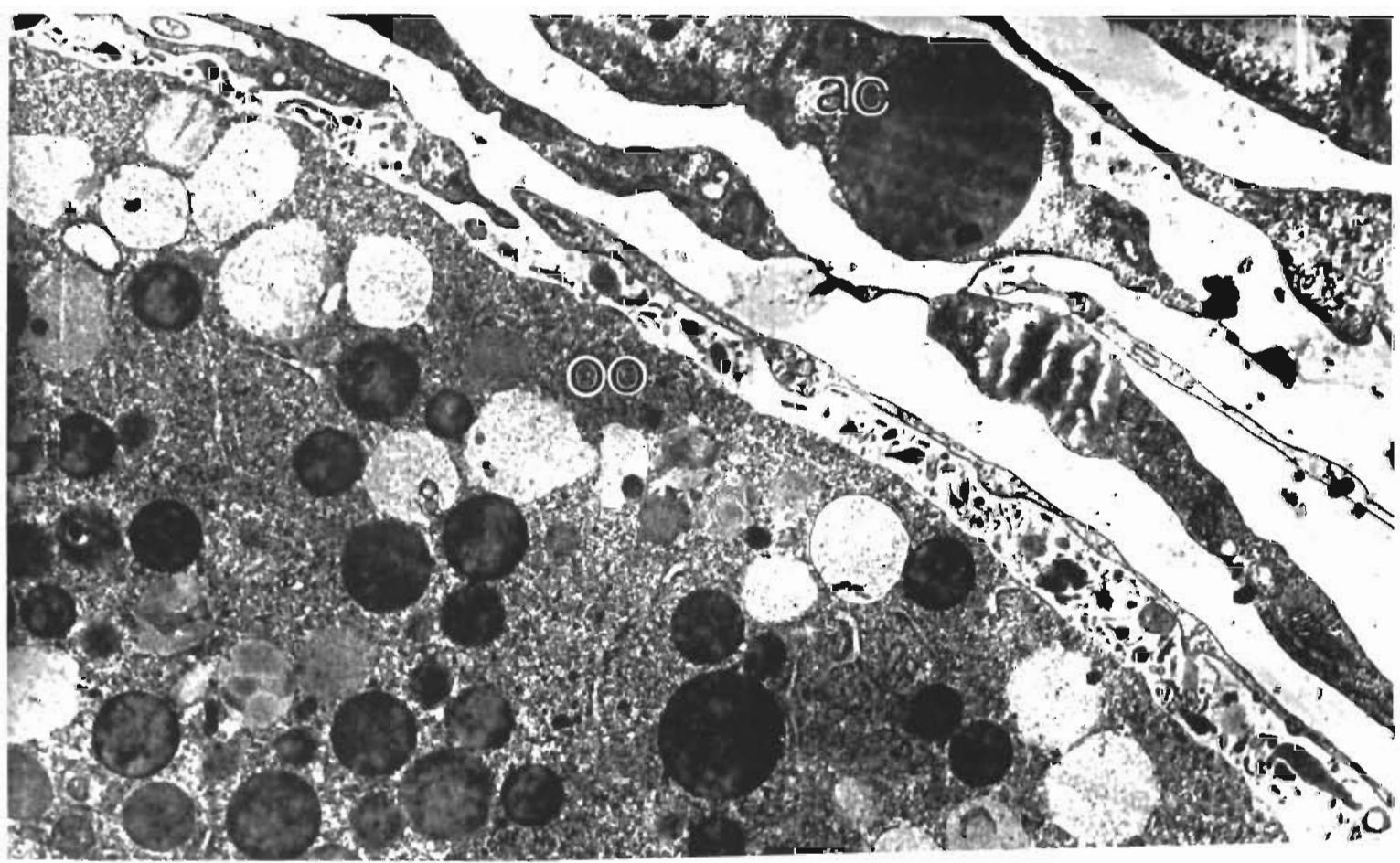

Fig. 7. Strongylocentrotus intermedius. Electronogram of processes of accessory cells near an oocyte in the gonad of control sea urchin. oo: oocyte; ac: accessory cells. $15000 \times$ 


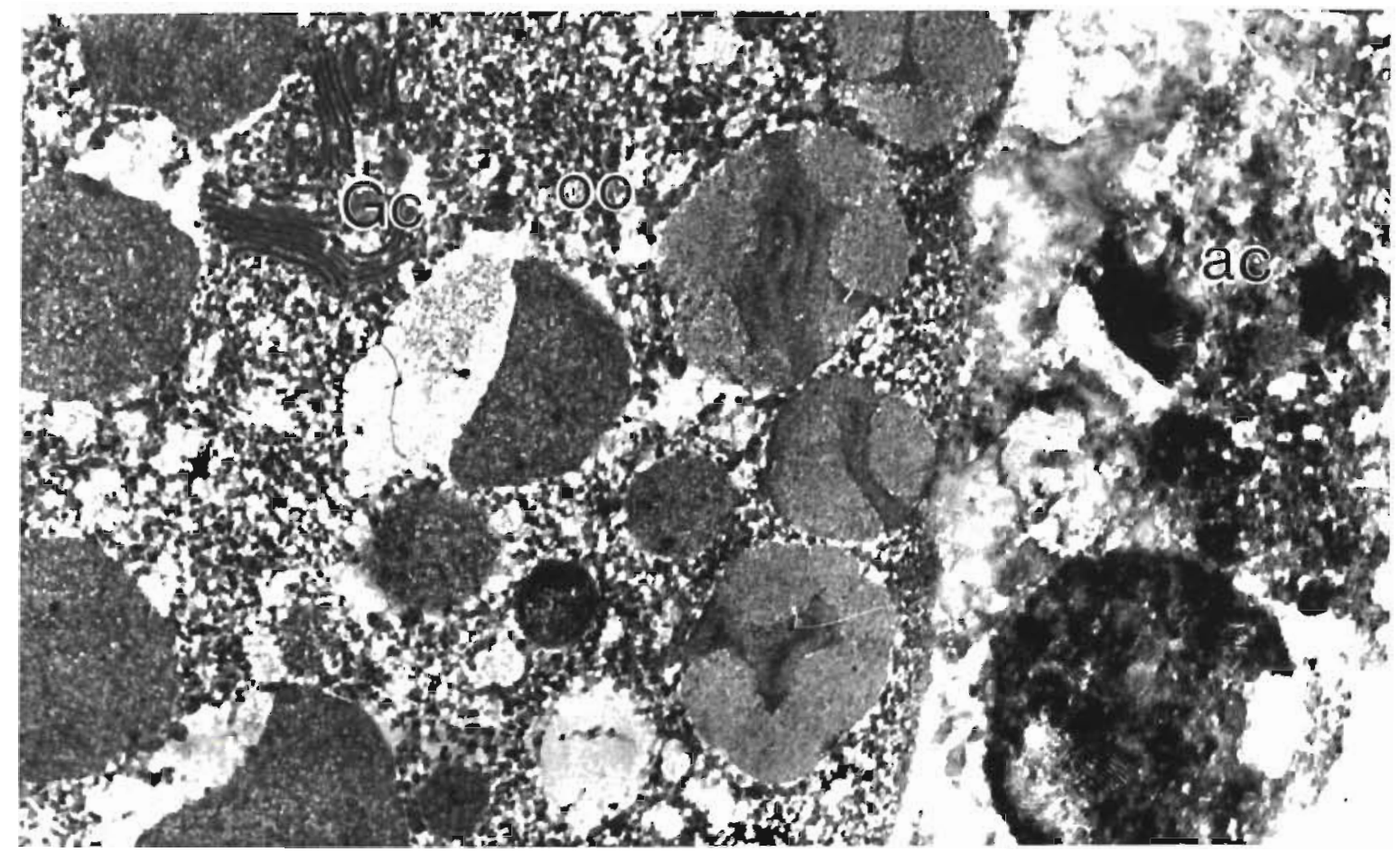

Fig. 8. Strongylocentrotus intermedius. Electronogram of destruction of processes of accessory cells near an oocyte in the gonad of sea urchin after Cd exposure. oo: oocyte; ac: accessory cells; Gc: Golgi complex. $25000 \times$

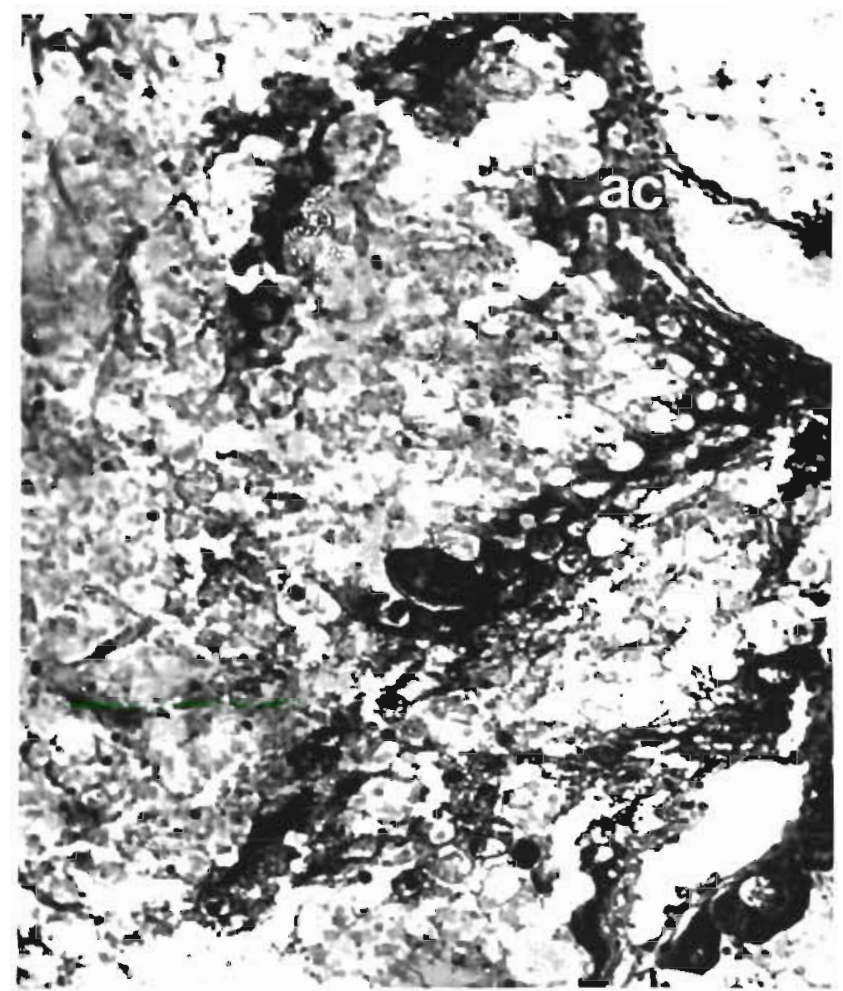

Fig. 9. Strongylocentrotus intermedius. Micrograph of destruction of acini in sea urchin gonad after long $\mathrm{Cd}$ exposure. ac: accessory cells. Stain: Caracci hematoxylin. $480 \times$

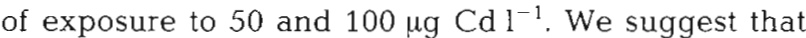
accumulation of sex cells in the gonad was connected with a start in gamete resorption. Probably, this is an adaptive response of the organism to the effects of cadmium; it uses the potential of the sex gland to produce a great number of gametes and thus to recover from gamete loss caused by resorption.

Obvious pathological changes were observed in the gonad structure after $40 \mathrm{~d}$ of exposure to 50 and $100 \mu \mathrm{g}$ $\mathrm{Cd} \mathrm{l}^{-1}$ : degeneration of some previtellogenic and vitellogenic oocytes increased. Resorption of sex cells has been described by several authors for invertebrates in nature. Large oocytes degenerate in winter and unspawned egg cells are resorbed after spawning in the sea urchins Strongylocentrotus intermedius and $S$. nudus, in the starfish Asterina gibbosa and in the mussel Crenomytilus grayanus (Motavkin \& Varaksin 1983). In our study, destruction of previtellogenic oocytes in the sea urchin $S$. intermedius occurred with exposure to cadmium. Cadmium is similarly known to cause lysis of gametes in Mytilus edulis (Myint \& Tyler 1982).

Further obvious pathological changes were found in test sea urchins after $130 \mathrm{~d}$ of cadmium exposure. By this time, many gametes were resorbed and some acini destroyed. It was found that resorption of oocytes involved accessory cells which utilize the material of degenerating oocytes. Gigantic heterophagosomes 
containing oocyte remains and utilizing this matter then appear in the cytoplasm of accessory cells (Takashima et al. 1978).

The mechanism of gonadotoxic effect of cadmiun is in detail still unknown, but there are several hypotheses developed for vertebrates. It has been found that the testes are most sensitive to cadmium; they show pathological changes earlier than other organs. Based on available evidence, Raitsina (1982) proposed that pathogenesis of cadmium-dependent necrosis of testes is caused by specific damage to testis vessels and disturbances in permeability of Sertoli cells and the entire envelope of seminiferous tubules; the structures function as a hematotesticular barrier. The permeability disturbances and histological damage are responsible for destruction of cells of spermatogenic epithelium.

Like all echinoderms and in contrast to other marine animals, sea urchins possess little ability of ionic regulation (Prosser 1977). Our earlier experiments with $\mathrm{Cd}$ in concentrations of 50, 100 and more $\mu \mathrm{g} \mathrm{Cd}^{-1}$ showed that $\mathrm{Cd}$ is accumulated in the gonad (Khristoforova et al. 1984, Gnezdilova et al. 1985). Moreover, we found on chronic exposure of sea urchins to cadmium (Lipina \& Gnezdilova 1985, Lipina et al. 1987) that cadmium penetrating a gonad wall into the gonad is mostly included into accessory cells and vaguely differentiated sex cells, oogonia and oocytes of early protoplasmatic growth, and that it concentrates in the nuclei of these cells.

In the present work, sex cells degenerated earlier than accessory cells did. But only morphological changes in accessory cells serving supporting and trophic (Varaksina 1980) and barrier functions (Lipina \& Gnezdilova 1985) should be regarded as an indication of the onset of irreversible pathology in the sea urchin gonad. In addition to obvious damage to sex cells (resorption of some oocytes), cadmium is also responsible for general inhibition of gonad development: in the control every third oocyte became ripe by the end of the experiment, but acini of test specimens contained only a few egg cells.

A temporal increase in the number of sex cells, which can be explained as a compensatory reaction, did not prove to be sufficient for complete recovery of the reproductive function of the gonad. In spite of continuous growth of the number of attached oocytes in comparison with the control, resorption progressed and involved growing gametes, accessory cells and entire acini.

Hence, cadmium effect is responsible for resorption of gametes and, on the other hand, for an increase in the number of oogonia and attached oocytes in the sea urchin Strongylocentrotus intermedius. An increased production of sex cells shows that the sex gland is able to respond to a damaging impact and, consequently, the pattern of gametogenesis could be used as an indication of the functional state of organisms for estimating biological responses to changes in environmental situations.

Acknowledgement. The authors thank Professor A.V Zhirmunsky for critical reading of the manuscript.

\section{LITERATURE CITED}

Evdokimov, V. V. (1974). Experimental regulation of gametogenesis in sea urchins. Cand. Biol. Sci thesis, Institute of Marine Biology, FESC, USSR Acad. Sci., Vladivostok. (In Russian)

Gnezdilova, S. M. (1971). Morphological and histochemical characteristics of oogenesis and sex cells in the sea urchins Strongylocentrotus nudus, $S$. intermedius. Cand. Biol. Sci. thesis, Institute of Marine Biology, FESC, USSR Acad. Sci., Vladivostok. (Russian)

Gnezdilova, S. M., Khristoforova, N. K., Lipina, I. G. (1985). Gonadotoxic and embryotoxic effects of cadmium in sea urchins. Symposia Biological Hungarica 29: 239-251

Khesin, Ya. E. (1967). Sizes of nuclei and functional state of cells. Medicine, Moscow

Khristoforova, N. K., Gnezdilova, S. M., Vlasova, G. A. (1984). Effect of cadmium on gametogenesis and offspring of the sea urchin Strongylocentrotus intermedius. Mar. Ecol. Prog. Ser. 17: 9-14

Lipina, I. G., Gnezdilova, S. M. (1985). Cadmium distribution in the gonads of the sea urchins Strongylocentrotus nudus and S. intermedius. Mar. Biol., Vladivostok 4: 50-53. (Russian; English summary)

Lipina, I. G., Gnezdilova, S. M., Khristoforova, N. K. (1987). Experimental study of cadmium distribution in gonads of the sea urchin Strongylocentrotus intermedius. Mar. Ecol. Prog. Ser. 36: 263-266

Motavkin, P. A., Varaksin, A. A. (1983). Histophysiology of the nervous system and regulation of reproduction in bivalve molluscs. Nauka, Moscow

Myint, U. M., Tyler, P. A. (1982). Effects of temperature nutritive and metal stressors on the reproductive biology of Mytilus edulis. Mar. Biol. 67: 209-223

Prosser, L. (1977). Comparative physiology of animals, Vol. 1 Mir, Moscow. (Russian transl.)

Raitsina, O. S. (1982). Hemotesticular barrier. In: Detlaf, T A (ed.) Contemporary problems of spermatogenesis. Nauka, Moscow, p. 29-34 (Russian)

Takashima, Y., Tominaga, Kume, T. (1978). Formation and behaviour of the nurse cell giant granules in the sea urchin ovary. 9th Int. Congr. Electron. Microsc. Toronto, Vol. 2, p. $554-555$

Varaksina, G. S. (1980). Morphology of accessory cells during the reproductive cycle of sea urchins. Mar. Biol., Vladivostok 5: 38-44. (Russian; English summary)

Westernhagen, H. von, Rosenthal, H., Sperling, K.-R. (1974) Combined effects of cadmium and salinity on development and survival of herring eggs. Helgoländer wiss. Meeresunters. 26: 416-433

Zaroogian, G. E., Morrison, G. (1981). Effect of cadmium body burdens in adult Crassostrea virginica in fecundity and viability of larvae. Bull. environ. Contam. Toxicol. 27: $334-348$ 